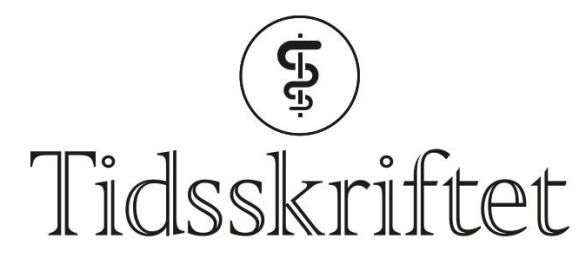

DEN NORSKE LEGEFORENING

\title{
Bjørn Jan Lie
}

MINNEORD

NAVNEET SINGH

PARVEEN WADHWA

ANNA MARIA PERSVOLD

ELLEN SOFIE THORSEN

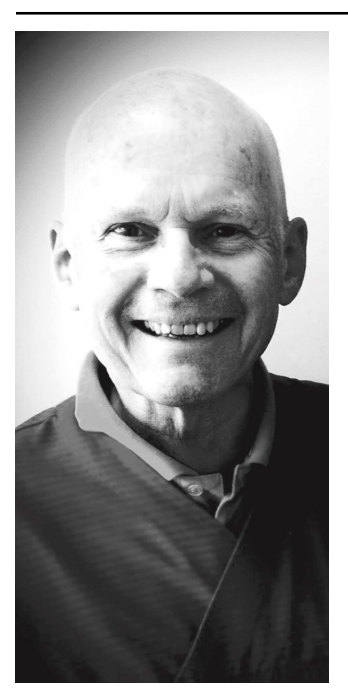

Det var med stor sorg at vi mottok budskapet om Bjørn Jan Lies (17.8.1945-16.4.2020) bortgang. Vi har mistet en god venn og kollega.

Bjørn vokste opp på Nordstrand i Oslo. Han studerte medisin ved Westfälische WilhelmsUniversität Münster i Tyskland. Han fikk sin embetseksamen i 1975, startet i turnustjeneste samme år ved Drammen sykehus og gjennomførte distriktstjeneste i Årdalstangen i Sogn og Fjordane. Han forble distriktslege der frem til 1980. Da startet han som allmennlege i Oppsal bydel i Oslo og deretter ved Dyretråkket legekontor i Bydel Søndre Nordstrand i 1984. Han forble ved Dyretråkket som fastlege frem til han pensjonerte seg i 2017.

Som lege var Bjørn elsket av pasienter, medarbeidere og kollegaer. Han spredte glede og god stemning på kontoret med sine mange historier, gode humør og varme vesen. Han var svært kunnskapsrik og tilbød alltid en hjelpende hånd når vi yngre kollegaer sto fast. Da bidro han også med smarte triks og råd som ikke nødvendigvis var beskrevet i lærebøkene. Dette kom spesielt til nytte ved behandling av barn, for Bjørn forsto barn på en spesiell måte og klarte alltid å skape tillit selv hos de mest skeptiske. 
Bjørn hadde talegaver og en språkstil som gagnet pasientene i legeerklæringer, henvisninger og journalnotat. Han var en ordkunstner og kunne virkelig beskrive pasientens utfordringer og plager på en treffende måte. Han var pasientenes advokat og sto på for de svakeste i samfunnet. Ingenting gjorde Bjørn mer sint enn når en urett var begått mot en pasient.

Bjørn elsket jobben sin som fastlege. Da sykdommen kom, måtte han motvillig pensjonere seg "prematurt» i en alder av 72 år.

Hvil i fred Bjørn. Våre varme tanker går til Astrid, Magnus, Fredrik, Erik og Sverre.

På vegne av Alpha Legegruppe

Publisert: 17. august 2020. Tidsskr Nor Legeforen. DOI: 10.4045/tidsskr.20.0550

(C) Tidsskrift for Den norske legeforening 2020. Lastet ned fra tidsskriftet.no 